\title{
Insertion of the v-Ha-ras Oncogene Induces Differentiation of Calcitonin-producing Human Small Cell Lung Cancer
}

\author{
Mack Mabry, “ Toshitaro Nakagawa, ${ }^{*}$ Stephen Baylin, ${ }^{\star}$ Olive Pettengill, ${ }^{\circ}$ George Sorenson, ${ }^{\star}$ and Barry Nelkin \\ *Johns Hopkins Oncology Center, Baltimore, Maryland 21231; and ${ }^{\ddagger}$ Department of Pathology, \\ Dartmouth Medical School, Hanover, New Hampshire 03755
}

\begin{abstract}
Human small cell lung cancers (SCLC) and cell lines derived therefrom are phenotypically heterogeneous concerning neuroendocrine differentiation. Unlike most SCLC tumors and cell lines that express poorly differentiated neuroendocrine phenotypes, the SCLC cell line DMS 53 exhibits mature endocrine differentiation features, including unusually high expression of the gene for the peptide hormone, calcitonin (CT). We now report that introduction of the viral Harvey ras $\left(\mathrm{v}-\mathrm{ras}^{\mathrm{H}}\right)$ oncogene into DMS 53 cells via retroviral infection, with resultant constitutive expression, results in increased features of neuroendocrine differentiation. 7-10 d after infection the cells demonstrated altered morphology, increased CT secretion, increased CT gene expression, markedly diminished cellular proliferation, and nearly abolished methylcellulose cloning efficiency. This response of DMS 53 cells to $\mathrm{v}-\mathrm{ras}^{\mathrm{H}}$ is unlike the tumor progression effects we have previously observed in other SCLC lines. Significantly, the differentiation response that follows expression of the virally introduced $v-$ ras $^{H}$ oncogene in DMS 53 cells is similar to that of neoplastic neuroendocrine cell lines derived from adrenal pheochromocytes and thyroid C cells. The effects of constitutive v- ras $^{\mathrm{H}}$ expression in DMS 53 SCLC cells and other neuroendocrine cell lines suggest an important role for ras $^{\mathrm{H}}$ or related genes in neuroendocrine differentiation.
\end{abstract}

\section{Introduction}

Human small cell lung cancer (SCLC) ${ }^{1}$ in cell culture exhibits a range of phenotypes that may reflect both the differentiation state of the bronchial cell of origin and ongoing progression of events during tumor development. Cultures of SCLC hence

This paper was presented in part at the International Conference on Hormones, Growth Factors, and Oncogenes in Pulmonary Carcinoma, 30 August-2 September 1987, Hanover, NH, and published in abstract form (1987. Lung Cancer. 3:110).

Address correspondence to Dr. Mack Mabry, Johns Hopkins Oncology Center, Bond Street Laboratories, 424 N. Bond Street, Baltimore, MD 21231.

Received for publication 19 August 1988 and in revised form 28 February 1989.

1. Abbreviations used in this paper: CGRP, calcitonin gene-related peptide; CT, calcitonin; Ha-MSV, Harvey murine sarcoma virus; MTC, medullary thyroid carcinoma cells; SCLC, small cell lung cancers; v-ras ${ }^{\mathrm{H}}$, viral Harvey ras oncogene.

J. Clin. Invest.

(c) The American Society for Clinical Investigation, Inc.

0021-9738/89/07/0194/06 \$2.00

Volume 84, July 1989, 194-199 represent important human cell systems to explore molecular events that regulate phenotypic alterations of normal and neoplastic epithelial cells.

Most SCLC lines, termed classic SCLC, have properties similar to tumors in patients, including high expression of markers typical of early neuroendocrine cell development and a modest degree of endocrine differentiation $(1,2)$. A significant number of other SCLC lines, characterized as biochemical variant or morphologic variant SCLC, have decreased levels of these same endocrine differentiation markers, increased proliferative indices, amplification of the c-myc gene, and growth patterns and biochemical markers more typical of non-SCLC $(1,2)$. The SCLC line DMS 53 is unique because it demonstrates more differentiated endocrine features than typically found in classic and variant cells. These include high levels of specific small polypeptide hormones in addition to expression of early neuroendocrine markers $(3,4)$.

We have been interested in the genetic and biochemical signals that mediate differentiation of these cell phenotypes in the SCLC lineage and recently have shown that when the viral Harvey ras oncogene $\left(\mathrm{v}-\mathrm{ras}^{\mathrm{H}}\right)$ is expressed via retroviral infection in variant SCLC, these cells acquire features typical of large cell lung cancer cell lines including adherent growth, increased growth rate, augmented cloning efficiency, resistance to the polyamine analogue $\alpha$-difluoromethylornithine, and further loss of neuroendocrine markers (5). However, when classic SCLC cells similarly express high levels of $\mathrm{v}-\mathrm{ras}^{\mathbf{H}}$, their growth characteristics, drug sensitivity, and neuroendocrine markers were not affected (5).

SCLC cells with more mature endocrine features were not initially studied, and hence pose an interesting question with regard to differentiation responses within the SCLC cell lineages. In nonpulmonary neuroendocrine neoplastic cell lines from well-defined endocrine tissues, increasing ras gene expression or microinjection of its $\mathrm{p} 21$ protein product results in acquisition of a more differentiated state (6-9). Such results

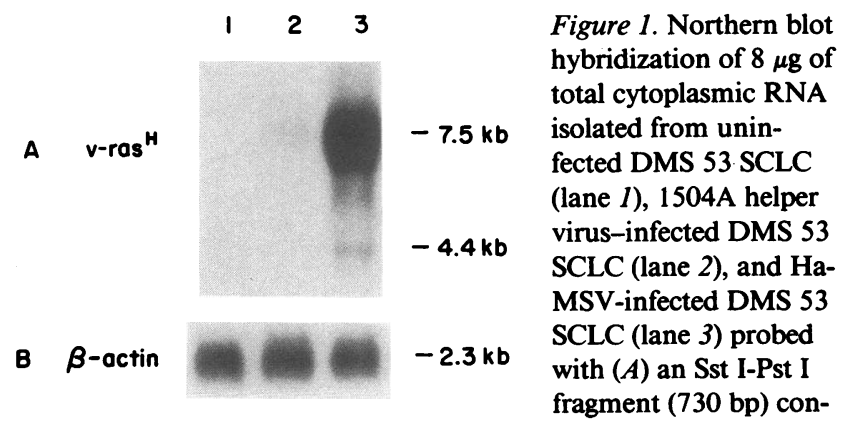

taining only the $\mathrm{v}-\mathrm{ras}^{\mathrm{H}} \mathrm{p} 21$ coding region (Oncor) and $(B) \beta$-actin. Note high expression of $\mathrm{v}-\mathrm{ras}^{\mathrm{H}}$ in Ha-MSV infected DMS 53 cells (lane 3). $\beta$-Actin signals demonstrate equivalent loading in each lane. 

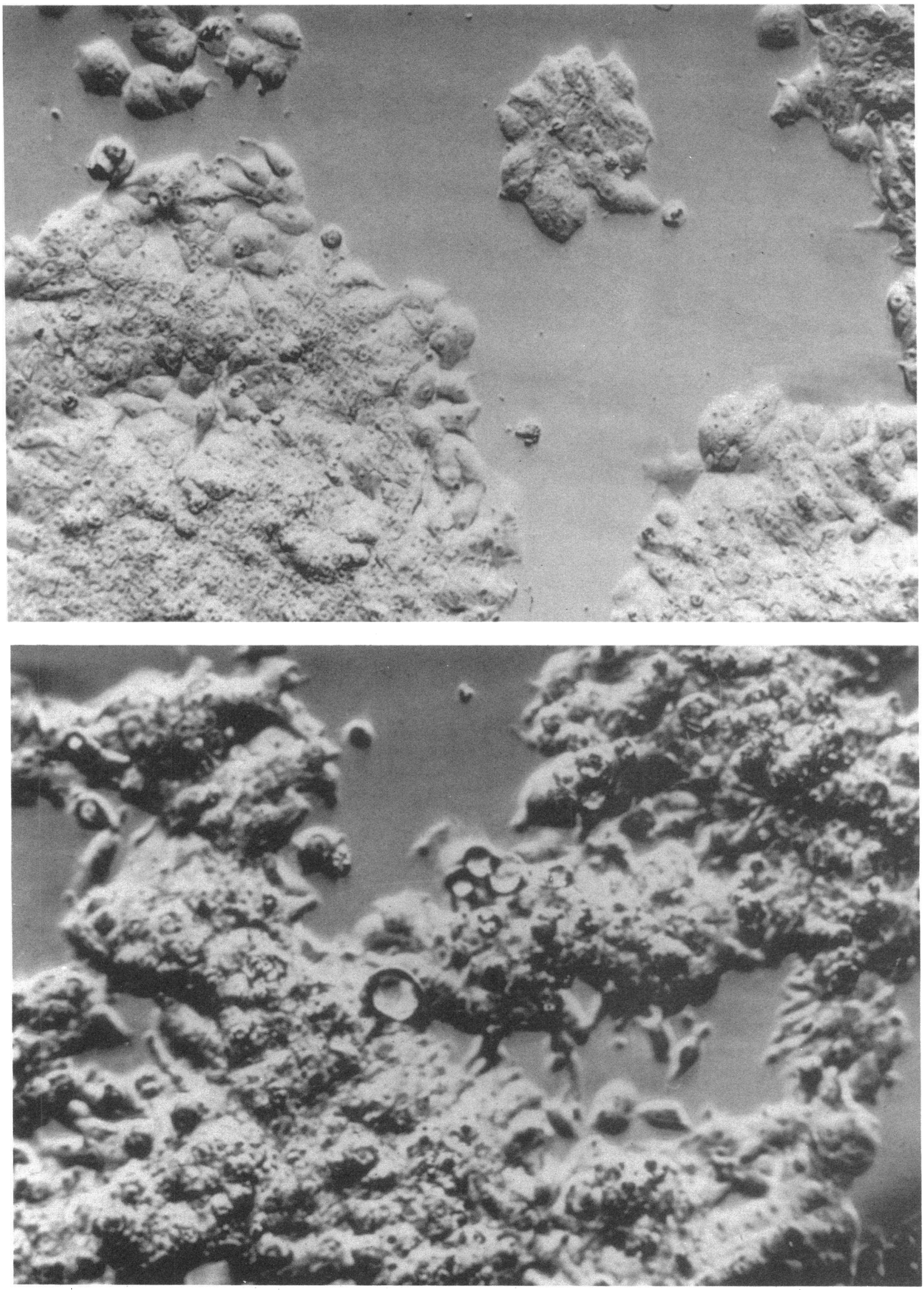

Figure 2. Photomicrographs of uninfected DMS 53 cells (top) and Ha-MSV DMS 53 cells $7 \mathrm{~d}$ after infection (bottom). Note morphological alteration from a flat monolayer in uninfected cells (top) to rounded, larger cells growing as mounds of cells (bottom). No morphologic changes were noted in DMS 53 SCLC cells infected with 1504A helper virus alone. $\times 200$. 


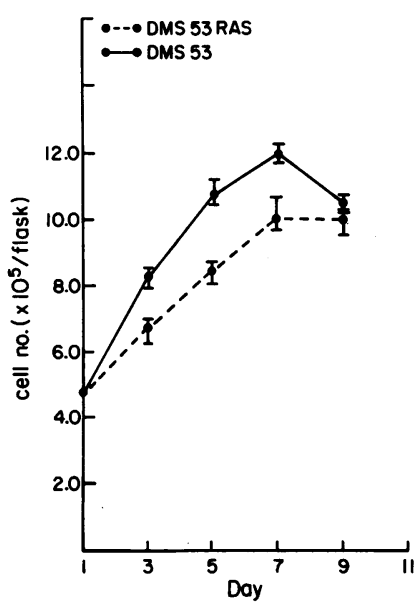

Figure 3. Growth curves of Ha-MSV infected and uninfected DMS 53 SCLC cells. Cell number was determined after trypsinization using an automated cell counter (Coulter Electronics Inc.). Each point represents the mean $( \pm \mathrm{SD})$ of triplicate wells in three separate experiments. No alterations in growth were found in DMS 53 cells infected with 1504A helper virus alone.

have been obtained with rat PC 12 pheochromocytoma cells (6-8) and, in our laboratory, with human medullary thyroid carcinoma cells (MTC) (9). SCLC line DMS 53 has phenotypic similarity to MTC in that expression of the calcitonin (CT) gene and resultant CT hormone secretion is extremely high (3, 4). We speculated that the effects of introduction and constitutive expression of $\mathrm{v}$-ras ${ }^{\mathrm{H}}$ in DMS 53 cells might then differ from the effects of $\mathrm{v}-\mathrm{ras}^{\mathrm{H}}$ expression in other SCLC lines, and might instead result in acquisition of differentiation-associated features, such as increased CT gene expression and decreased growth. We now demonstrate that $\mathrm{v}-$-as $^{\mathrm{H}}$ expression will differentiate DMS 53 SCLC cells. Our findings emphasize further that mutated ras genes can supply critical functions for altering cell phenotypes in human lung cancer, and that the responses obtained depend on the initial differentiation status of the cell. These data support an important role for ras or other genes with similar functions in regulating endocrine cell differentiation and show that ras gene expression in specific types of cultured tumor cells with pronounced neuroendocrine characteristics can cause a decrease in phenotypic features associated with malignancy.

\section{Methods}

Cell culture and viral infection. Cells of a well-characterized culture line of human SCLC, DMS $53(3,4)$, were grown at $37^{\circ} \mathrm{C}$ in Waymouth's media supplemented with $16 \% \mathrm{vol} / \mathrm{vol}$ of heat-inactivated fetal bovine serum (Gibco Laboratories, Grand Island, NY), 2 mM glutamine, 100 $\mathrm{U}$ penicillin, and $100 \mathrm{mg}$ streptomycin sulfate $/ \mathrm{ml}$ in a humidified $\mathrm{CO}_{2}$ incubator. The v-ras ${ }^{\mathrm{H}}$ gene was introduced into DMS 53 cells using our previously described conditions (5, 9-11). Briefly, NIH 3T3 cells, infected with. Harvey murine sarcoma virus (Ha-MSV) and 1504A amphotropic murine leukemia helper virus, as well as NIH 3T3 cells infected with 1504A amphotropic murine leukemia helper virus alone, were grown in DME (Gibco Laboratories) supplemented with 9\% (vol/vol) heat-inactivated fetal bovine serum. For viral infection, DMS 53 cells were exposed to conditioned medium from the infected NIH 3T3 cells which contained high titers of Ha-MSV and 1504A helper virus or supernatant containing 1504A helper virus alone. Efficiency of infection of DMS 53 SCLC cells was increased by use of Polybrene (Sigma Chemical Co., St. Louis, MO) at $1.0 \mu \mathrm{g} / \mathrm{ml}$.

Growth studies. $10 \mathrm{~d}$ after viral infection the cells were harvested by trypsinization and seeded in $25-\mathrm{cm}^{2}$ polystyrene flasks at a density of $2.0 \times 10^{5} \mathrm{cells} / \mathrm{ml}$. Cell numbers were determined using an automatic cell counter (Coulter Electronics Inc., Hialeah, FL) and periodically confirmed by hemocytometer counts.
Cloning efficiency. DMS 53 cells infected with Ha-MSV and uninfected DMS 53 controls were suspended at a density of 10,000 cells $/ \mathrm{ml}$ in $1.8 \%$ methylcellulose in growth medium. The methylcellulose/cell suspension was layered over a $3 \%$ agar base. Colonies were evaluated and scored at day 10. Cloning efficiency was calculated as the number of colonies per plate divided by the number of cells suspended. The data reported are results of three independent experiments, each containing quintuplicate samples.

Secretion of calcitonin. Supernatant from Ha-MSV-infected or uninfected DMS 53 cells was centrifuged $(1,500 \mathrm{~g}, 3 \mathrm{~min})$ and the concentration of CT in the supernatants was determined by RIA (12) and normalized to cell number. Culture media not exposed to cells had no detectable CT levels.

cDNA probes. CT (pTT1062) and CT gene-related peptide (CGRP) (pTT42) cDNA probes have been described (13). pTT1062 contains only human CT-specific sequences (exon 4). Neither CGRP-specific sequences (exons 5-6), nor sequences common to both CT and CGRP (exons 1-3), are found in this probe. pTT83 contains a Pvu II-Pst I restriction fragment from pTT42 which contains only CGRP-specific sequences including $17 \mathrm{bp}$ of exon 5 and all of exon 6 of the CT gene (13).

Recombinant plasmids containing human $\beta$-actin sequences were provided by D. Cleveland (Johns Hopkins University School of Medicine, Baltimore, MD). An Sst-Pst I fragment (730 bp) containing only the $\mathrm{v}-\mathrm{ras}^{\mathrm{H}}$ gene $\mathrm{p} 21$ coding region was obtained from Oncor (Gaithersburg, MD). All probes were labeled with $\left[{ }^{32} \mathrm{P}\right] \mathrm{dCTP}$ by nick translation to a sp act of $\sim 5 \times 10^{8} \mathrm{cpm} / \mu \mathrm{g}$ of DNA.

$R N A$ hybridization. Cytoplasmic RNA was extracted by NP-40 lysis in the presence of vanadyl ribonucleoside complex as previously described $(12,14) .8 \mu \mathrm{g}$ of total or $4 \mu \mathrm{g}$ of poly $\mathrm{A}^{+}$selected cytoplasmic RNA for Northern blot hybridization analysis was electrophoresed in a $6 \%$ formaldehyde/1.2\% agarose gel and transferred to nitrocellulose. Filters were hybridized in $5 \times$ SSPE $(1 \times$ SSPE $=150 \mathrm{mM} \mathrm{NaCl}, 10 \mathrm{mM}$ Na phosphate, $1 \mathrm{mM}$ EDTA), $10 \%$ formamide, $1 \%$ SDS, $60 \mathrm{mg} / \mathrm{ml}$ polyethylene glycol $8,000,5 \mathrm{mg} / \mathrm{ml}$ powdered milk, and $200 \mu \mathrm{g} / \mathrm{ml}$ sonicated salmon sperm DNA for $16 \mathrm{~h}$ at $42^{\circ} \mathrm{C}$. After hybridization filters received a final wash with $0.1 \times$ standard saline citrate, $\mathrm{pH}$ $7.0 / 0.1 \% \mathrm{SDS}$ at $65^{\circ} \mathrm{C}$ for $30 \mathrm{~min}$. For autoradiography, films were exposed for $24-36 \mathrm{~h}$ at $-70^{\circ} \mathrm{C}$. Hybridizations and quantitation of signal for CT and $\beta$-actin RNAs by densitometry were performed as described $(12,13)$.

\section{Results}

Efficient viral infection and resultant constitutive expression of $\mathrm{v}$-ras ${ }^{\mathrm{H}}$ occurred after infection of DMS 53 cells with $\mathrm{Ha}$ MSV. Northern blots of total cytoplasmic RNA (8 $\mu \mathrm{g})$ hybridized with a 730-bp Sst I-Pst I fragment containing only the $\mathrm{v}-$ ras $^{\mathrm{H}}$ coding region showed levels of $\mathrm{v}-$ ras $^{\mathrm{H}} \mathrm{mRNA}$ that were $10^{3}$-fold greater than the levels of endogenous $\mathrm{c}$-ras ${ }^{\mathrm{H}}$ transcripts detected in uninfected control cells when probed with the above viral probe (Fig. 1) or with a probe for the human c-ras ${ }^{\mathrm{H}}$ gene (data not shown). Transcripts homologous to the $\mathrm{v}-\mathrm{ras}^{\mathrm{H}}$ coding region probe, under our hybridization conditions, were not detected in uninfected control cells nor those infected with helper virus alone.

Within $7 \mathrm{~d}$ after infection with Ha-MSV, DMS 53 cells developed marked morphological changes. Cells became more rounded and larger, with increased cytoplasm to nucleus ratio, and had a less pyknotic nuclear pattern with prominent nucleoli. While DMS 53 cells normally grow as a flat confluent monolayer, after Ha-MSV infection they grew as rounded mounds of cells (Fig. 2). No morphologic alterations were observed after infection with the amphotropic helper virus alone.

Growth of DMS 53 was markedly reduced after infection 

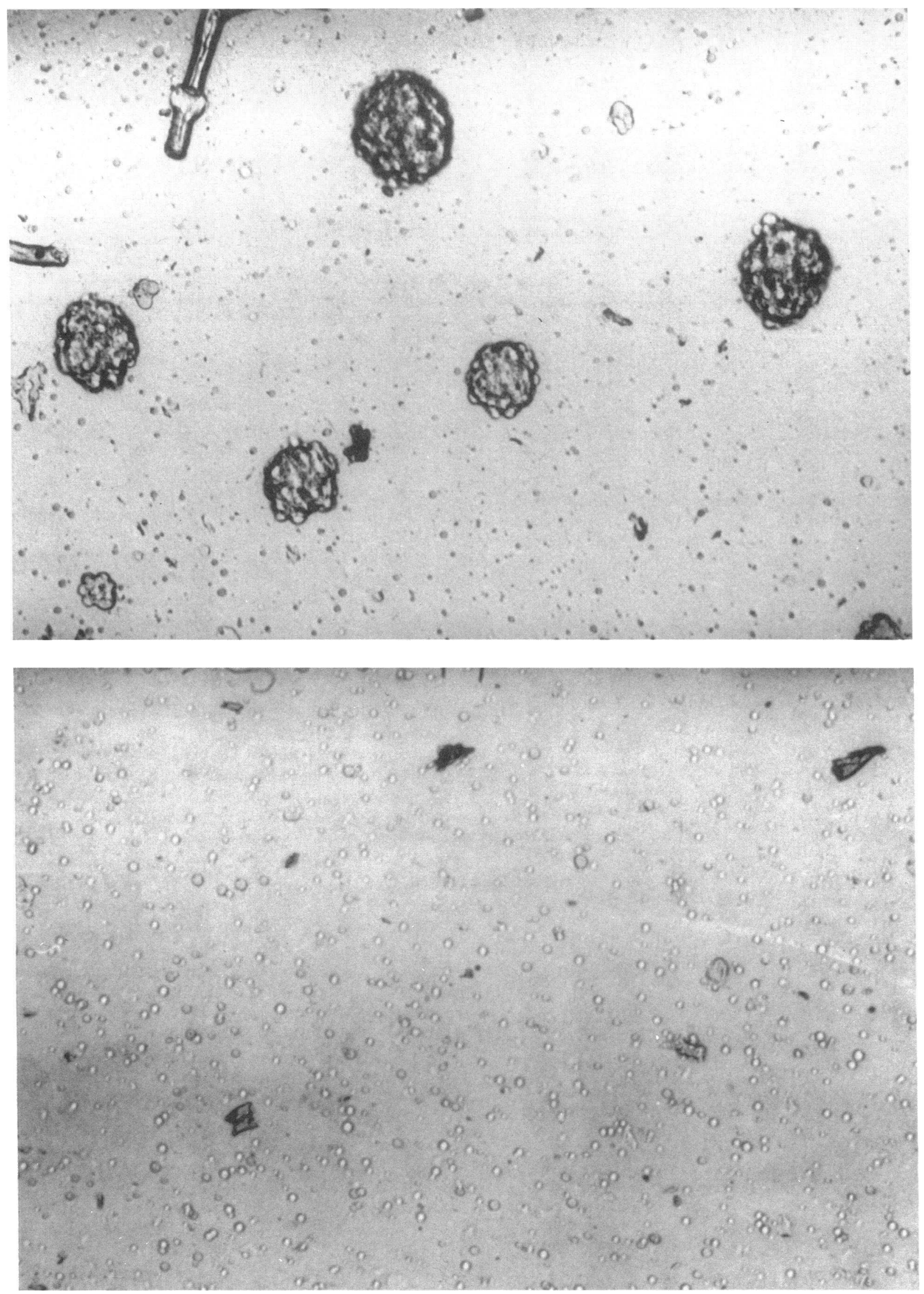

Figure 4. Photomicrographs of methylcellulose/agar plates of uninfected DMS 53 SCLC cells $(A)$ and Ha-MSV-infected DMS 53 SCLC cells $(B)$. Note the presence of multiple large clones of cells in DMS 53 SCLC $(A)$. In contrast, Ha-MSV-infected DMS 53 SCLC (B) shows no clones present. DMS 53 SCLC cells infected with Ha-MSV removed from the methylcellulose suspensions remained viable as assessed by trypan blue dye exclusion. Clones were counted at day 10. 
with Ha-MSV. Cell doubling times were increased from 36 to $70 \mathrm{~h}$ (Fig. 3). Decreased growth was accompanied by marked reduction in cloning efficiency. Cloning efficiency in methylcellulose-agar was reduced from 8.2 to $0.2 \%$ after induction of the $\mathrm{v}-\mathrm{ras}^{\mathrm{H}}$ expression (Fig. 4). DMS 53 cells expressing v$\operatorname{ras}^{\mathrm{H}}$ remained viable as assessed by trypan blue staining after their removal from the methylcellulose suspensions.

Decreased growth often accompanies cell differentiation. Our previous studies of human MTC (9) demonstrated that $\mathrm{v}-\mathrm{ras}^{\mathrm{H}}$ infection resulted in diminished growth and induction of a program of differentiation that included a marked increase in expression of the neuroendocrine peptide hormone gene, CT. DMS 53 SCLC cells, which also produce high basal levels of $\mathrm{CT}$, might be expected to increase CT production in response to differentiation. Fig. 5 shows that increased CT secretion occurs after infection with Ha-MSV. Consistent with this product increase, the Ha-MSV-infected cells had increased expression of CT mRNA (Fig. 6). It is interesting that the increase involves only one of the two major mRNA species generated by alternative processing of the CT gene. One of these species, CT mRNA, contains exons 1, 2, 3, and 4 and is elevated threefold. However, the other major mRNA species from the CT gene, which encodes CGRP, and which is derived from exons $1,2,3,5$, and $6(13,15)$, did not increase after expression of the virally introduced $\mathrm{v}-$ - $^{\mathrm{H}}{ }^{\mathrm{H}}$ oncogene (Fig. 6).

\section{Discussion}

In many cell types, ras gene overexpression or mutation is associated with neoplastic transformation or progression (5, 16-23). However, previous studies in two well-defined neuroendocrine tumor cell lines, rat pheochromocytoma cell line PC 12 (6-8) and human MTC (9), demonstrated that expression of an exogenously introduced ras gene or gene product can induce features of neuroendocrine differentiation. We now show that neoplastic endocrine cells that arise from the complex background of the bronchial epithelium, and which are putative progenitors of the cancer SCLC, differentiate in a fashion similar to human MTC and PC 12 after expression of the virally introduced $\mathrm{v}-\mathrm{ras}^{\mathrm{H}}$ oncogene. We observed acquisition of differentiation-associated features which include a decrease of such tumorigenic properties as the ability of the cells to clone, and a reduced cell growth fraction. In contrast, no phenotypic alterations were observed in DMS 53 SCLC cells

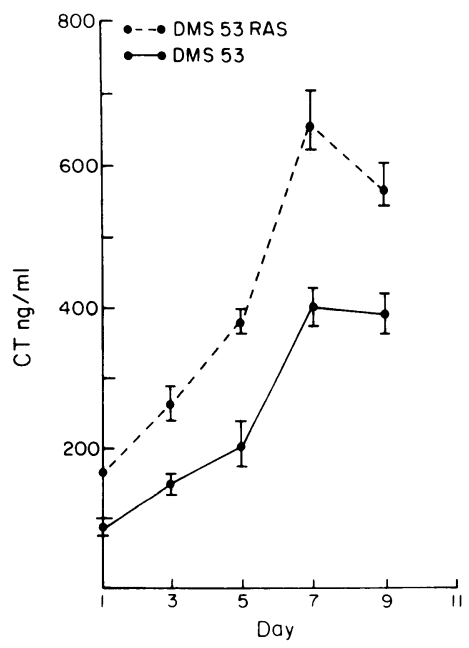

Figure 5. CT secretion of DMS 53 SCLC cells and DMS 53 SCLC cells infected with Ha-MSV. 7 d after viral infection the cells were trypsinized and seeded at $2.0 \times 10^{5}$ cells/ well. CT content in the media was measured by RIA at indicated time points. No differences in CT secretion were seen with 1504A helper virus alone. Each point represents mean $( \pm S D)$ of triplicate wells for three separate experiments.

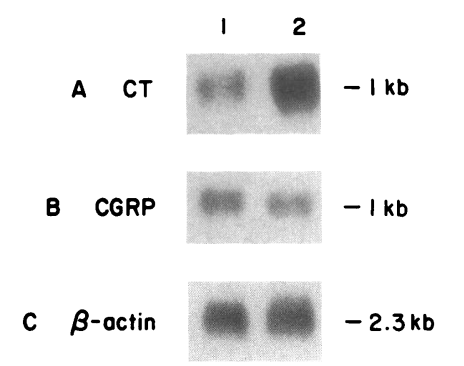

Figure 6. (A) Hybridization of $8 \mu \mathrm{g}$ of DMS 53 SCLC control and Ha-MSV-infected DMS 53 SCLC total cytoplasmic RNA with the CT-specific exon 4 probe pTT1062. Note increased CT mRNA in DMS 53 SCLC infected with HaMSV (lane 2) compared with uninfected controls (lane 1 ).

(B) Hybridization of $4 \mu \mathrm{g}$ of poly $\mathrm{A}^{+}$selected DMS 53 SCLC control and Ha-MSV-infected DMS 53 SCLC mRNA with CGRP-specific pTT83 probe. No alteration in CGRP expression is observed. $(C) \beta$-Actin controls indicate equivalent loading in each lane.

solely infected with 1504A amphotrophic helper virus alone. These data suggest that acquisition of differentiation-associated features in response to ras expression may be specific for cells of distinct neuroendocrine phenotypes.

Our results in cell culture appear to correlate with recent observations in vivo regarding ras gene expression and neuroendocrine cell differentiation. For example, high levels of the ras gene protein product $\mathrm{p} 21$ have been demonstrated by immunohistochemistry in differentiated neural or neuroendocrine tissue (24). Moreover, increased expression of $\mathrm{ras}^{\mathrm{H}}$ protein product $\mathrm{p} 21$ predicts favorable prognoses in patients with neuroblastoma (25). These results suggest that ras or related genes may have an important role in maintenance of neuroendocrine phenotypes.

The data obtained from the DMS 53 SCLC cell line are especially significant when viewed in the context of our previous work with v-ras ${ }^{\mathrm{H}}$ and SCLC (5). SCLC cell lines with partially developed neuroendocrine features, termed classic SCLC, demonstrated no phenotypic alterations of growth, morphology, biochemical markers, or drug sensitivity after the virally introduced $\mathrm{v}-\mathrm{ras}^{\mathrm{H}}$ gene was expressed. Biochemical variant SCLC acquired non-SCLC features and demonstrated features of tumor progression (5). Thus, the response to v-ras ${ }^{\mathrm{H}}$ expression seen in SCLC cells appears to be dependent on the phenotypic context of the recipient cell.

The molecular mechanisms by which the ras gene influences endocrine cell differentiation and the behavior of lung cancer cells may relate to the functions of the ras gene products, which may mediate signal transduction events. Our data with DMS 53 SCLC, which shares neuroendocrine features with MTC and PC 12 cells, suggests that ras-mediated transduction events may replace functions lost after transformation of pulmonary endocrine cells. The differential phenotypic responses in SCLC lines after $\mathrm{v}-\mathrm{ras}^{\mathrm{H}}$ expression may reflect the different responses that normal bronchial epithelial cells may exhibit in response to expression of ras or related genes in vivo during cell renewal and differentiation. Elucidation of the specific genetic and biochemical events responsible for the differential responses to expression of virally introduced $\mathrm{v}$-ras ${ }^{\mathrm{H}}$ in different SCLC cell lines should provide important information regarding the mechanisms through which alterations of genes such as ras $^{\mathrm{H}}$ may promote or interfere with normal differentiation processes. The model systems offered by cultured human lung cancer cells with differential phenotypic responses to the $r a s^{\mathrm{H}}$ gene provide unique means to pursue these questions. 


\section{Acknowledgments}

We thank Dr. Paul Celano, Dr. Robert Casero, Dr. Andree de Bustros, and Dr. Nancy Davidson for helpful discussions, Dr. Alan Rein for providing Ha-MSV and helper virus, Dr. Don Cleveland for the human $\beta$-actin probe, Ms. Sara Lyles for CT RIAs, Ms. Kathleen Wieman for making the figures, and Ms. Sandra Lund and Ms. Tammy Hess for typing the manuscript.

This work was partly supported by Training Grant NRSA 1532 CA08207-02 (to Dr. Mabry) and R01-CA48081-01 from the National Institutes of Health.

\section{References}

1. Carney, D. N., A. F. Gazdar, G. Bepler, J. G. Guccion, P. J. Marangos, T. W. Moody, M. H. Zweig, and J. D. Minna. 1985. Establishment and identification of small cell lung cancer cell lines having classic and variant features. Cancer Res. 45:2913-2923.

2. Gazdar, A. F., D. N. Carney, M. M. Nau, and J. D. Minna. 1985. Characterization of variant subclasses of cell lines derived from small cell lung cancer having distinctive biochemical, morphological, and growth properties. Cancer Res. 45:2924-2930.

3. Sorenson, G. D., O. S. Pettengill, T. Brinck-Johnson, C. C. Cate, and L. H. Maurer. 1981. Hormone production by cultures of small-cell carcinoma of the lung. Cancer (Phila.). 47:1289-1296.

4. Cate, C. C., O. S. Pettengill, and G. D. Sorenson. 1986. Biosynthesis of procalcitonin in small cell carcinoma of the lung. Cancer Res. 46:812-818.

5. Mabry, M., T. Nakagawa, B. D. Nelkin, E. McDowell, M. Gesell, J. C. Eggleston, R. A. Casero, Jr., and S. B. Baylin. 1988. Viral harvey ras oncogene insertion: a model for tumor progression of small cell lung cancer. Proc. Natl. Acad. Sci. USA. 85:6523-6527.

6. Hagag, N., S. Halegoua, and M. Viola. 1986. Inhibition of growth factor-induced differentiation of $\mathrm{PC} 12$ cells by microinjection of antibody to ras p21. Nature (Lond.). 319:680-682.

7. Bar-Sagi, D., and J. R. Feramisco. 1985. Microinjection of the ras oncogene protein into PC12 cells induces morphological differentiation. Cell. 42:841-848.

8. Noda, M., M. Ko, A. Ogura, P. G. Liu, T. Amano, T. Takano, and Y. Ikawa. 1985. Sarcoma viruses carrying ras oncogenes induce differentiation-associated properties in a neuronal cell line. Nature (Lond.). 318:73-75.

9. Nakagawa, T., M. Mabry, A. de Bustros, J. N. Ihle, B. D. Nelkin, and S. B. Baylin. 1987. Introduction of v-Ha-ras oncogene induces differentiation of cultured human medullary thyroid carcinoma cells. Proc. Natl. Acad. Sci. USA. 84:5923-5927.

10. Rein, A., J. Keller, A. M. Schultz, K. L. Holmes, R. Medicus, and J. N. Ihle. 1985. Infection of immune mast cells by Harvey sarcoma virus: immortalization without loss of requirement for interleukin-3. Mol. Cell. Biol. 5:2257-2264.
11. Rein, A., A. M. Schultz, J. P. Bader, and R. H. Bassin. 1982. Inhibitors of glycosylation reverse retroviral interference. Virology. 119:185-192.

12. de Bustros, A., S. B. Baylin, M. A. Levine, and B. D. Nelkin. 1986. Cyclic AMP and phorbol esters separately induce growth inhibition, calcitonin secretion, and calcitonin gene transcription in cultured human medullary thyroid carcinoma. J. Biol. Chem. 261:8036-8041.

13. Nelkin, B. D., K. I. Rosenfeld, A. de Bustros, S. S. Leong, B. A. Roos, and S. B. Baylin. 1984. Structure and expression of a gene encoding human calcitonin and calcitonin gene related peptide. Biochem. Biophys. Res. Commun. 123:648-655.

14. Maniatis, T., E. F. Fritsch, and J. Sambrook. 1982. In Molecular Cloning: A Laboratory Manual. Cold Spring Harbor Laboratory, Cold Spring Harbor, NY. 191-203.

15. Amara, S. G., V. Jonas, M. G. Rosenfeld, E. S. Ong, and R. M. Evans. 1982. Alternative RNA processing in calcitonin gene expression generates mRNAs encoding different polypeptide products. $\mathrm{Na}$ ture (Lond.). 298:240-244.

- 16. Harvey, J. J. 1964. An unidentified virus which causes the rapid production of tumours in mice. Nature (Lond.). 204:1 104-1 105.

17. Scher, C. D., E. M. Scolnick, and R. Siegler. 1975. Induction of erythroid leukaemia by Harvey and Kirsten sarcoma viruses. Nature (Lond.). 256:225-226.

18. Yoakum, G. H., J. F. Lechner, E. W. Gabrielson, B. E. Korba, L. Malan-Shibley, J. C. Willey, M. G. Valerio, A. M. Shamsuddin, B. F. Trump, and C. C. Harris. 1985. Transformation of human bronchial epithelial cells transfected by Harvey ras oncogene. Science (Wash. DC). 227:1174-1179.

19. Rhim, J. S., G. Jay, P. Arnstein, F. M. Priu, K. K. Sanford, and S. A. Aaronson. 1985. Neoplastic transformation of human epidermal keratinocytes by AD12-SV40 and Kirsten sarcoma viruses. Science (Wash. DC). 227:1250-1252.

20. Pierce, J. H., and S. A. Aaronson. 1982. BALB- and Harveymurine sarcoma virus transformation of a novel lymphoid progenitor cell. J. Exp. Med. 156:873-887.

21. Yuspa, S. H., A. E. Kilkenny, J. Stanley, and U. Lichti. 1985. Keratinocytes blocked in phorbol ester-responsive early stage of terminal differentiation by sarcoma viruses. Nature (Lond.). 314:459-462.

22. Weissman, B. E., and S. A. Aaronson. 1983. BALB and Kirsten murine sarcoma viruses alter growth and differentiation of EGF-dependent balb/c mouse epidermal keratinocyte lines. Cell. 32:599-606.

23. Hankins, W. D., and E. M. Scolnick. 1981. Harvey and Kirsten sarcoma viruses promote the growth and differentiation of erythroid precursor cells in vitro. Cell. 26:91-97.

24. Furth, M. E., T. H. Alehrich, and C. Cordon-Cardo. 1987. Expression of ras proto-oncogene proteins in normal human tissues. Oncogene. 1:47-58.

25. Tanaka, T., D. J. Slamon, H. Shimoda, C. Waki, Y. Kawaguchi, Y. Tanaka, and N. Ida. 1988. Expression of Ha-ras oncogene products in human neuroblastomas and the significant correlation with a patient's prognosis. Cancer Res. 48:1030-1034. 